How to Cite: Salkeeva, L.K., Muratbekova, A.A., Minayeva, E.V., Voitichek, P., Tayshibekova, E.K., Dostanova, A.R., Tateeva, A.B., \& Salkeeva, A.K. (2021) Phosphorylation of glycoluryl derivatives with phosphorus pentachloride. Bulletin of the University of Karaganda-Chemistry, 101(1), 12-18. https://doi.org/10.31489/2021Ch1/12-18

UDC 547:794.3

\author{
L.K. Salkeeva ${ }^{1 *}$, A.A. Muratbekova ${ }^{1}$, E.V. Minayeva ${ }^{1}$, P.Voitichek $^{2}$, \\ E.K. Tayshibekova ${ }^{1}$, A.R. Dostanova ${ }^{1}$, A.B. Tateeva ${ }^{1}$, A.K. Salkeeva ${ }^{3}$ \\ ${ }^{1}$ Karagandy University of the name of academician E.A. Buketov, Kazakhstan; \\ ${ }^{2}$ Charles University, Prague, Czech Republic; \\ ${ }^{3}$ Karaganda Technical University, Kazakhstan \\ (*Corresponding author's e-mail: lsalkeeva@mail.ru)
}

\title{
Phosphorylation of glycoluryl derivatives with phosphorus pentachloride
}

\begin{abstract}
The paper presents the research results on the synthesis and study of new organophosphorus derivatives of glycoluril, obtained on the basis of pentavalent phosphorus. New organoelement phosphorus derivatives synthesized on the basis of $\mathrm{N}$-acyl-substituted glycoluril have been obtained. They are of considerable interest due to the presence of effective reaction centers. Tetraacetyl-substituted glycoluril - 2,4,6,8-tetraacetyl2,4,6,8-tetraazabicyclo[3,3,0]octane-3,7-dione was chosen as the initial synthon. The use of unsubstituted glycoluril in the reaction of direct phosphorylation by the action of phosphorus trichloride or pentachloride is not possible due to the absence of active phosphorylation centers. It was experimentally shown that the reaction proceeds with prolonged heating for at least 48 hours in an argon. The initial acyl derivative of glycoluril and phosphorus pentachloride in the ratio of 1:6 and leads to the formation of diphosphonic complex of tetraacetylglycoluril - dihexachlorophosphorate 2,6-diacetyl-(4,8-diacetyl-2,4,6,8-tetraazabicyclo[3.3.0]octane-3,7-dione)-2,6-di(chloroethenyltrichlorophosphonium). The obtained compound is a white crystalline substance unstable in air. Decomposition of the diphosphonic complex was carried out using benzaldehyde and proceeds with the formation of the corresponding dichlorophosphate derivative, also unstable in air and rapidly decomposing at room temperature.
\end{abstract}

Keywords: glycoluril, bicyclic bisureas, phosphorus pentachloride, phosphorylation, N-acylation, phosphorus, bicyclic, synthesis.

\section{Introduction}

Currently the synthesis of 2,4,6,8-tetraazabicyclo[3.3.0.]octane-3,7-dione (glycoluril) derivatives and the study its properties remain one of the rapidly developing areas of modern chemistry of heterocyclic compounds. This substance is a representative of the bicyclic bisureas class. Glycolurils find wide application in various areas of industry: in particular, resins containing glycoluril are used for the manufacture of paints and coatings; in the pulp and paper industry, the application of glycoluril is also known as an intermediate product in the synthesis of antioxidants, detergents, disinfectants and bleaching agents [1-3].

All these properties of glycoluril make it a promising object among the researchers as this class of compounds possesses with many undiscovered potential properties. The first reports on the interaction of glycoluril and acetic anhydride with the formation of $\mathrm{N}$-acetyl-substituted glycoluril derivatives date back to the beginning of the last century [4-8]. Despite the diversity of the N-acetyl-substituted bicyclic bisureas series, it was noted the N-acylation of glycoluril was limited by the synthesis of N,N-di- and N,N,N,Ntetraacetylated derivatives. It is obvious the possibilities of the glycoluril acylation reaction are larger and varied.

It is known N-substituted glycolurils have a wide spectrum of biological activity. Previously it was reported about the neuroleptic, antidepressant and psychostimulating activity of glycoluril and its derivatives. This property is the main reason that arouses a great interest in the syntheses of the new group compounds capable to show various activities.

Organic phosphorus compounds are also used in a different areas of human life and the synthesis of new organophosphorus derivatives with various biological activity continues to be a priority.

\section{Experimental}

Equipment. NMR spectra were recorded by a JeolECX-400 spectrometer for NMR (400 MHz) relatively TMS, for ${ }^{31} \mathrm{P}$ NMR $(162 \mathrm{MHz})$ versus an external standard $\left(85 \% \mathrm{H}_{3} \mathrm{PO}_{4}\right)$ and for ${ }^{13} \mathrm{C} \mathrm{NMR}(100 \mathrm{MHz})$ versus an internal standard - TMS in DMSO-solutions. $\mathrm{d}_{6}, \mathrm{CDCl}_{3}, \mathrm{D}_{2} \mathrm{O}$. IR spectra were recorded with the FSM-1201 Fourier spectrometer from $450 \mathrm{~cm}^{-1}$ to $4000 \mathrm{~cm}^{-1}$ in $\mathrm{KBr}$ pellets. NMR spectra were recorded in 
the medium of argon. Mass spectra were recorded by a MicroTOF instrument (ESI-TOFMS), Bruker. Melting points were determined by the MP50 MeltingPointSystem.

The reactions procedure and the compounds identity were monitored by thin layer chromatography on standard Silufol UV-254 plates in the benzene: ethyl alcohol $=6: 1$ system. The plates were detected with iodine vapor and a UV lamp.

Synthesis of 2,4,6,8-tetraacetyl-2,4,6,8-tetraazabicyclo[3,3,0]octane-3,7-dione (1)

$153.0 \mathrm{~g}(1.5 \mathrm{~mol})$ of acetic anhydride and $1 \mathrm{ml}(0.01-0.02 \mathrm{~mol})$ of $56 \%$ perchloric acid were added to the $35.0 \mathrm{~g}(0.25 \mathrm{~mol})$ of glycoluril with stirring. The mixture was heated until self-heating began. After complete homogenization, $20.0 \mathrm{~g}(0.2 \mathrm{~mol})$ of sodium acetate was added to the reaction mixture and was boiled for an hour. The reaction mixture was cooled, the precipitated crystals were filtered off and washed with acetic anhydride and dried. Yield is $65.7 \mathrm{~g}(89 \%)$, m.p. $244^{\circ} \mathrm{C}$. IR spectrum $\left(v, \mathrm{~cm}^{-1}\right): 1695(\mathrm{C}=\mathrm{O})$, $1780\left(\mathrm{COCH}_{3}\right) .{ }^{1} \mathrm{H}$ NMR spectrum $(400 \mathrm{MHz}, \mathrm{DMSO}), \delta$, ppm: $2.34 \mathrm{~s}\left(12 \mathrm{H}, \mathrm{COCH}_{3}\right), 6.33 \mathrm{~s}(2 \mathrm{H}, \mathrm{CH})$. ${ }^{13} \mathrm{C}$ NMR spectrum $\left(\mathrm{CDCl}_{3}\right): 59.95(\mathrm{CH}), 148.65(\mathrm{CO}), 167.57\left(\mathrm{COCH}_{3}\right)$. Found, \%: $\mathrm{C} 46.93, \mathrm{H} 4.78$, $\mathrm{N}$ 18.28. $\mathrm{C}_{12} \mathrm{H}_{14} \mathrm{~N}_{4} \mathrm{O}_{6}$. Calculated, \%: C 46.45, H 4.52, N 18.06.

Synthesis of hexachlorophosphorate of 2,6-di(4,8-diacetyl-2,4,6,8-tetraazabicyclo[3.3.0]octane-3,7dione)-2-hloroethenyltrichlorophosphonium (2)

$2.0 \mathrm{~g}(0.0064 \mathrm{~mol})$ of tetraacetylglycoluril in chloroform was added to $21.5 \mathrm{~g}(0.103 \mathrm{~mol})$ of phosphorus pentachloride in chloroform and in argon, then was heated for 48 hours with stirring. In an inert atmosphere, the solvent was distilled off, the crystals decomposing in air were filtered off then dried in a vacuum. Yield is $3.97 \mathrm{~g}(56 \%),{ }^{31} \mathrm{P}$ NMR spectrum $\left(162 \mathrm{MHz}, \mathrm{CDCl}_{3}\right): \delta$, ppm.: $2.67\left(\mathrm{PCl}_{3}{ }^{+}\right),-97.03\left(\mathrm{PCl}_{6}\right)$.

Synthesis of 2,6-di(2-chloroethynyl)-4,8-diacetyl-2,4,6,8-tetraazabicyclo[3.3.0]octane-3,7-dione diphosphonic acid (3)

$3.8 \mathrm{~g}(0.035 \mathrm{~mol})$ of benzaldehyde was added to the suspension of $3.97 \mathrm{~g}(0.0035 \mathrm{~mol}) 2$ and dry toluene in an argon. After complete dissolution, the mixture was heated at $80-90{ }^{\circ} \mathrm{C}$ for 3 hours. The solvent and low-boiling fractions were distilled off in a vacuum and the residue decomposed in air was recrystallized with dichloromethane. Yield is $1.0 \mathrm{~g}(48 \%) .{ }^{1} \mathrm{H}$ NMR spectrum $\left(400 \mathrm{MHz}, \mathrm{CDCl}_{3}\right), \delta$, ppm: $2.46 \mathrm{~s}(6 \mathrm{H}$, $2\left(\mathrm{COCH}_{3}\right), 3.71-3.79 \mathrm{~m}(2 \mathrm{H}, 2 \mathrm{C}=\mathrm{CH}), 5.70 \mathrm{~s}(2 \mathrm{H}, \mathrm{CHCH}) .{ }^{31} \mathrm{P}$ NMR spectrum $\left(162 \mathrm{MHz}, \mathrm{CDCl}_{3}\right), \delta$, ppm: 5.29.

\section{Results and discussion}

A detailed analysis of the literature data shows the lack of related reports on the study in particular, the phosphorylation of glycoluril and its derivatives. Previously there was a possibility of effective using glycoluril phosphorus derivatives according to the classical scheme of the Arbuzov reaction, i.e. by the interaction of bisacetylbrom derivatives of glycoluril - 1,4-bis(bromoacetyl)tetra-hydroimidazo[4,5-d]imidazole-2,5 $\left({ }^{1} \mathrm{H},{ }^{3} \mathrm{H}\right)$ dione with triethylphosphate [9]. As a result of the reaction, \{(2,5-dioxohexahydroimidazo[4,5-d]imidazole-1,4-diyl)-bis(2-oxoethane-2,1-diyl)\}-bis(diethylphosphonate) was obtained as a non-distillable oil acid hydrolysis of which gave the corresponding \{(2,5-dioxohexahydroimidazo[4,5-d]imidazole-1,4-diyl)-bis(2-oxoethane-2,1-diyl) \} bisphosphonic acid.

Despite the wide range of possibilities for the chemical modification of trivalent phosphorus derivatives, pentavalent phosphorus derivatives continue to attract the attention of organic chemists as important synthons in the creating of new biologically active compounds.

The most promising reagent in the synthesis of trivalent phosphorus derivatives is undoubtedly phosphorus pentachloride. For the first time, the reaction of phosphorus pentachloride with methylene compounds was described in the nineteenth century.

Subsequently, various derivatives of styrenes, dienes, unsymmetrical ethylenes and acetylenes, ethers and esters of enols, as well as enamides were subjected to phosphorylation with phosphorus pentachloride. Most of these reactions were carried out at room temperature [10-12].

Continuing research in this direction, we attempted to synthesize for the first time a new organophosphorus compounds based on acylated derivatives of glycoluril. 2,4,6,8-Tetraacetyl-2,4,6,8tetraazabicyclo[3,3,0]octane-3,7-dione was chosen as an object in the phosphorylation reaction 1 . The use of unsubstituted glycoluril in the reaction of direct phosphorylation by the action of phosphorus trichloride or pentachloride is not possible due to the absence of active centers for phosphorylation.

The reaction proceeds on heating for 48 hours in an argon atmosphere in a dry chloroform medium, in the ratio 1:6. The reaction resulted in diphosphonic complex tetraacetylglycoluril - dihexachlorophos- 
phorate 2,6-di-(4,8-diacetyl-2,4,6,8-tetraazabicyclo[3.3.0]octane-3,7-dione) - 2,6-di(chloroethenyltrichlorophosphonium) 2 according to the following scheme:

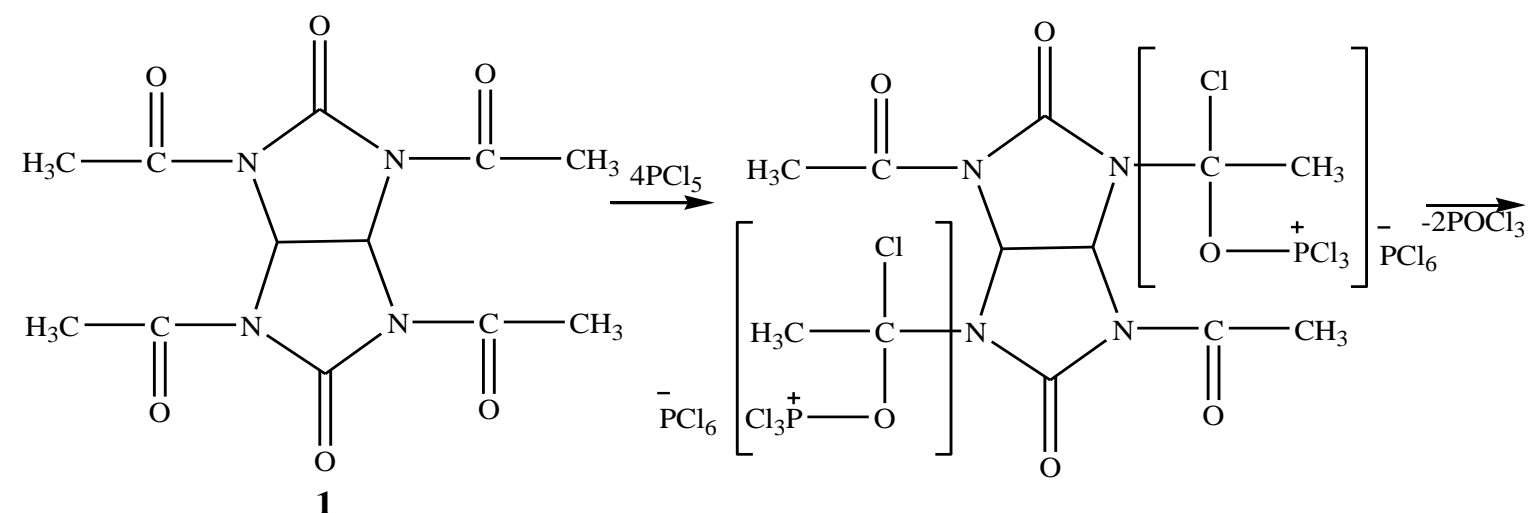

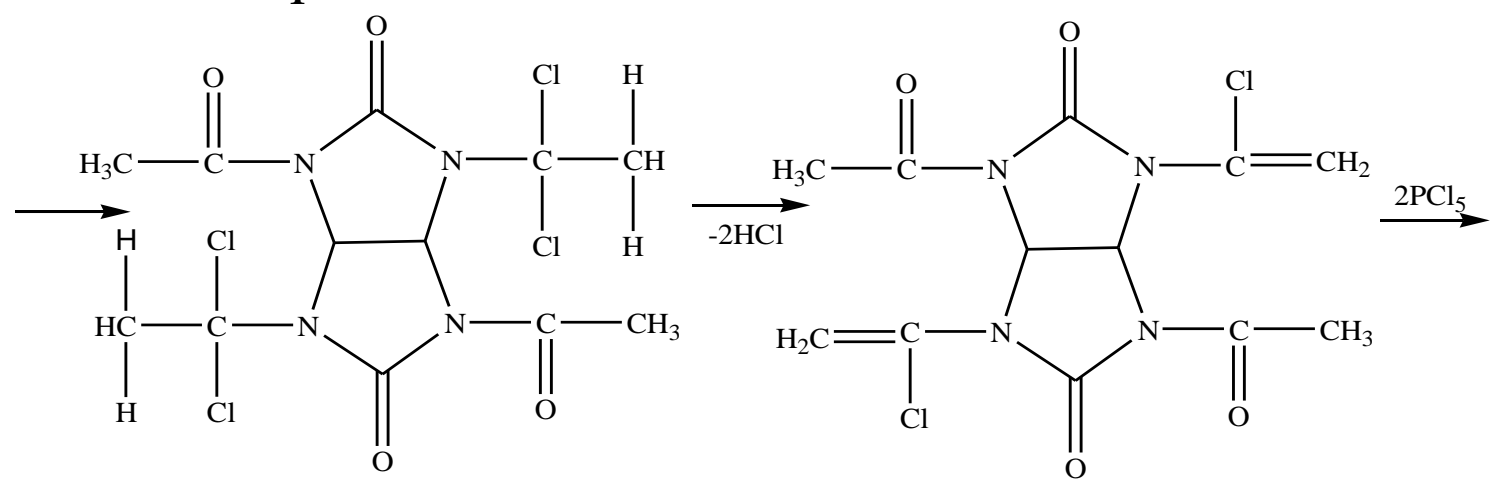

1a

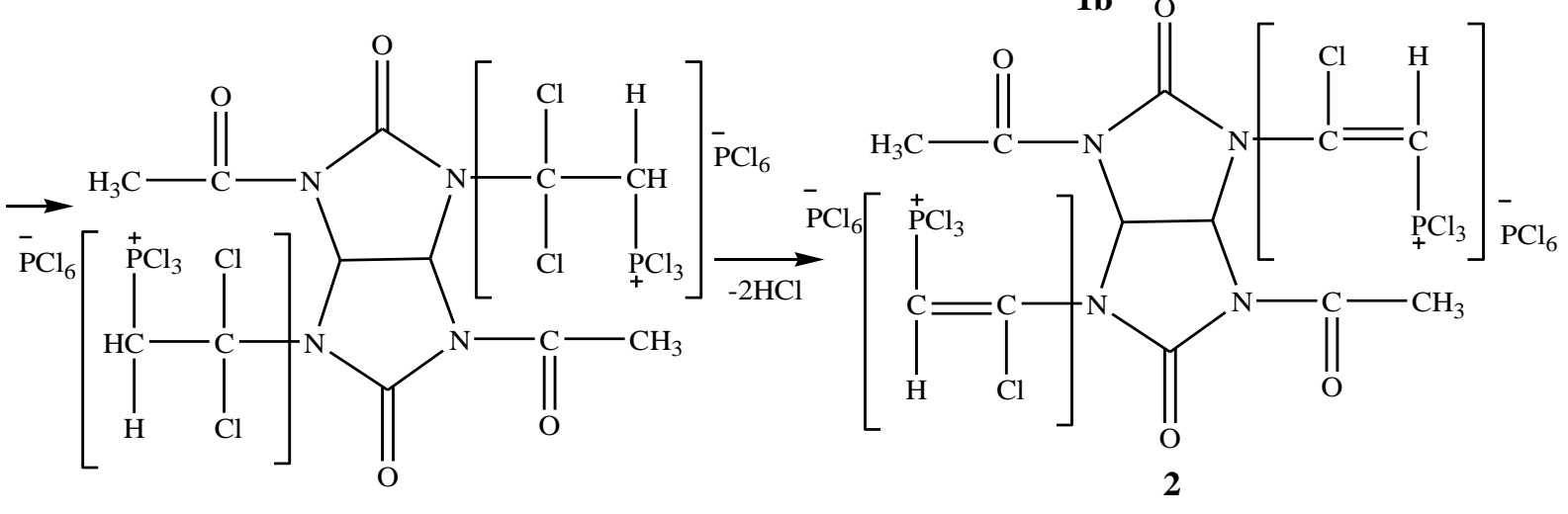

Figure 1. Phosphorylation of 2,4,6,8-tetraacetyl-2,4,6,8-tetraazabicyclo[3,3,0]octane-3,7-dione

The product is a white crystalline substance unstable in air.

Obviously, the reaction proceeds through the stage of phosphorus pentachloride addition to the oxygen atom of the acetyl group, and the resulting adduct gradually decomposes to intermediate $1 a$, which is dehydrochlorinated under the reaction conditions to unsaturated chlorine derivative $1 b$. Further, product $1 b$ is phosphorylated with phosphorus pentachloride forming the final product 2 .

The structure of compound 2 was proved by spectral data. In particular the ${ }^{31} \mathrm{P}$ NMR spectrum contains signals $2.67\left(\mathrm{PCl}_{3}^{+}\right)$and $-97.03\left(\mathrm{PCl}_{6}\right)$. Structure 2 shows that phosphorylation of 1 proceeds with the participation of two acetyl groups. The decomposition of the diphosphonic complex 2 was carried out using benzaldehyde and proceeds according to the following scheme: 


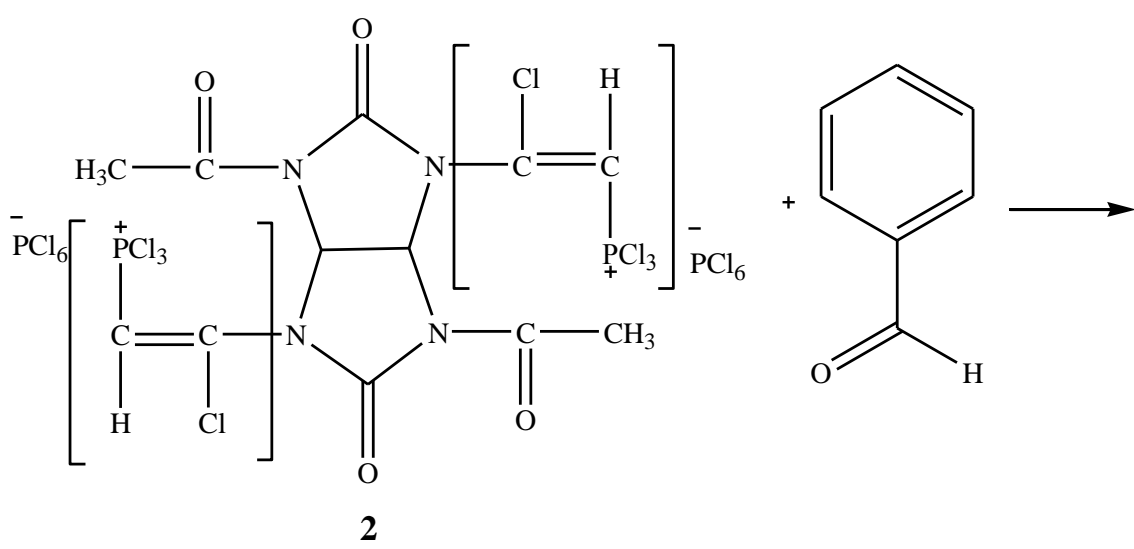<smiles>CC(=O)N1C(=O)N(C(Cl)=CP(=O)(Cl)Cl)C2C1N(C(C)=O)C(=O)N2C(Cl)=CP(=O)(Cl)Cl</smiles>

Figure 2. Decomposition of the diphosphonic complex with benzaldehyde

The structure of compound 3 was proved by spectral data. The ${ }^{1} \mathrm{H}$ NMR spectrum contains a signal of $2.46 \mathrm{ppm}$ corresponding to the presence of six protons of two $\mathrm{CH}_{3} \mathrm{CO}$ groups, a multiplet signal in the region of 3.71-3.79 ppm, corresponding to signals of two protons of $\mathrm{C}=\mathrm{CH}$ groups, and a singlet in the region of $5.70 \mathrm{ppm}$., which characterizes the signal of protons of $\mathrm{CHCH}$ groups; in the ${ }^{31} \mathrm{P}$ NMR spectrum there is a signal of $5.29 \mathrm{ppm}$ corresponding to the vibrations of the phosphorus atom.

\section{Conclusion}

The corresponding acylated derivatives of the bicyclic bisureas class i.e. glycoluril have been obtained according to the reaction of phosphorylation with phosphorus pentachloride for the first time. It was shown the reaction proceeds on heating for 48 hours in the argon and in dry chloroform with a sixfold excess of $\mathrm{PCl}_{5}$. The reaction leads to the formation of diphosphonic complex of tetraacetylglycoluril - dihexachlorophosphorate 2,6-di-(4,8-diacetyl-2,4,6,8-tetraazabicyclo[3.3.0]octane-3,7-dione)-2,6-di-(chloroethenyltrichlorophosphonium). This compound is a white crystalline substance unstable in air, the decomposition of which under the action of benzaldehyde leads to the corresponding 2,6-di-(2-chloroethynyl)-4,8-diacetyl2,4,6,8-tetraazabicyclo[3.3.0]octane-3,7-dione diphosphonic acid.

\section{References}

1 Bakibaev A.A. Synthetic anticonvulsants, antihypoxics, and inducers of the liver monooxygenase system based on amides and ureas. XVI. Studies of the antihypoxic properties of bicyclic bis-ureas / A.A. Bakibaev, V.K. Gorshkova, A.Yu. Yagovkin // Pharm. Chem. J. — 1994. — No. 8. - P. 547. https://doi.org/10.1007/BF02219026

2 Salkeeva L.K. Effect of Glycoluril and Its Derivatives on the Flame Resistance and Physicomechanical Properties of Rubber / L.K. Salkeeva, A.A. Bakibaev, G.T. Khasenova // Russian Journal of Applied Chemistry. — 2016. — Vol. 89, No. 1. — P. $132-$ 139.

3 Grillon E. Isolation and X-ray structure of the intermediate dihydroxyimidazolidine (DHI) in the synthesis of glycoluril from glyoxal and urea / E. Grillon, R. Gallo, M. Pierrot, J. Boileau // Tetrahedron Lett. - 1988. - Vol. 29, No. 9. — P. $1015-1016$. https://doi.org/10.1016/0040-4039(88)85322-X 
4 Jarvo E.R. Amino acids and peptides as asymmetric organocatalysts / E.R. Jarvo, S.J. Miller // Tetrahedron Lett. — 2002. № 58. - P 2481-2495. https://doi.org/10.1016/S0040-4020(02)00122-9

5 Christoffers J. Enantioselective Construction of Quaternary Stereocenters / J. Christoffers, A. Mann // Chem. Int. Ed. 2001. - No. 40. - P. 4591-4597.

6 Krause N. Recent advances in catalytic enantioselective Michael additions / N. Krause, A. Hoffmann-Roder // Synthesis. 2001. - P. 171-196.

7 Sibi M.P. Enantioselective conjugate additions / M.P. Sibi, S. Manyem // Tetrahedron. — 2000. — No. 56. - P. $8033-8061$. https://doi.org/10.1016/S0040-4020(00)00618-9

8 Leonard J. Control of Asymmetry Through Conjugate Addition Reactions / J. Leonard, E. Diez-Barra, S. Merino // Eur. J. Org. Chem. - 1998. - P. 2051-2061.

9 Бакибаев А.А. Тетраацетилгликолурил и некоторые его производные: синтез, свойства и применение / А.А. Бакибаев, Н.Ф. Хоанг, В.С. Мальков, С.И. Горбин, С.Ю. Паньшина // Изв. высш. учеб. зав. — 2019. — Т. 62, №. 9. C. 4-19. https://doi.org/10.6060/ivkkt.20196209.5924

10 Salkeeva L.K. New Phosphorylated Glycoluril Derivatives / L.K. Salkeeva, E.K. Taishibekova, A.A. Bakibaev, E.V. Minaeva, L.M. Sugralina, A.K. Salkeeva et al. // Russ. J. Gen. Chem. - 2017. - Vol. 87, No. 3. - P. 442. https://doi.org/10.1134/S1070363217030124

11 Пудовик А.Н. Реакции галоидангидридов кислот фосфора с непредельными соединениями / А.Н. Пудовик, В.К. Хайруллин // Успехи химии. — 1968. - Т. 37. - С. 745-777. https://doi.org/10.1070/RC1968v037n05ABEH001638

12 Промоненков В.К. Способы получения и свойства соединений с непредельными радикалами при атоме фосфора / $\begin{array}{lllllll}\text { В.К. Промоненков, С.З. Ивин } / / \text { Успехи химии. }-1968 . & - & \text { T. } 37 . & \text { C. } 1577-1599 .\end{array}$ https://doi.org/10.1070/RC1968v037n09ABEH001699

13 Kosolapoff G.M. Addition Reactions in Phospho-organic Syntheses. I. The Addition of Phosphorus Pentachloride to Olefins / G.M. Kosolapoff, W.F. Huber // J. Am. Chem. Soc. — 1946. — Vol. 68. — P. 2540-2541. https://doi.org/10.1021/ja01216a034

Л.К. Сәлкеева, А.А. Мұратбекова, Е.В. Минаева, П. Войтичек, Е.К. Тайшыбекова, А.Р. Достанова, А.Б. Тәтеева, А.К. Сәлкеева

\title{
Гликолурил туындыларын фосфордың пентахлоридімен фосфорлау
}

\begin{abstract}
Мақалада бесвалентті фосфор негізінде алынған гликолурилдің жаңа фосфорорганикалық туындыларын алу және олардың құрамын зерттеу бойынша жасалған ғылыми жұмыстың нәтижелері келтірілген. Тиімді реакция орталықтарының болуы себебінен өте жоғары қызығушылық тудыратын $\mathrm{N}$-ацил алмасқан гликолурил негізінде синтезделген фосфордың жаңа элементорганикалық туындылары алынған. Алғашқы синтон ретінде тетраацетил алмасқан гликолурил - 2,4,6,8-тетраацетил-2,4,6,8-тетраазабицикло[3,3,0]октан-3,7-дион алынды, себебі, үш немесе бесхлорлы фосфор әсерімен тікелей реакциясында алмаспаған гликолурилді қолдану фосфорлаудың белсенді орталықтары болмағандықтан мүмкін болмайды. Эксперимент нәтижесінде реакция өте ұзақ, 48 сағаттан аз емес уақыт аралығында, аргон атмосферасында алғашқы гликолурилдің ацил туындысы мен бесхлорлы фосфордың 1:6 қатынасында қыздыру арқылы іске асатыны көрсетілді. Реакция нәтижесінде ауада тұрақсыз, ақ кристалды зат болатын тетраацетилгликолурилдің - дигексахлорофосфорат 2,6-ди-(4,8-диацетил-2,4,6,8-тетраазабицикло[3.3.0]октан-3,7-дион)-2,6-ди(хлорэтенилтрихлорфосфония) дифосфоноды комплексі алынды. Дифосфоноды комплекстің ыдырауы бензальдегидті пайдалана отырып және ауада тұрақсыз болатын, бөлме температурасында тез ыдырайтын, сәйкес дихлорфосфатты туындының түзілуімен жүреді.
\end{abstract}

Кілт сөздер: гликолурил, бисмочевина, фосфорпентахлориді, фосфорлау, $\mathrm{N}$-ацилдеу, фосфор, бициклді, синтез.

\author{
Л.К. Салькеева, А.А. Муратбекова, Е.В. Минаева, П. Войтичек, \\ Е.К. Тайшибекова, А.Р. Достанова, А.Б. Татеева, А.К. Салькеева
}

\section{Фосфорилирование производных гликолурила пентахлоридом фосфора}

В статье представлены результаты научных исследований по синтезу и исследованию строения новых фосфорорганических производных гликолурила, полученных на основе пятивалентного фосфора. Синтезированы новые элементоорганические производные фосфора на основе $\mathrm{N}$-ацилзамещенных гликолурилов, представляющих значительный интерес благодаря наличию эффективных реакционных центров. В качестве исходного синтона был выбран тетраацетилзамещенный гликолурил 2,4,6,8-тетраацетил-2,4,6,8-тетраазабицикло[3,3,0]октан-3,7-дион, так как использование незамещенного гликолурила в реакции прямого фосфорилирования действием трех- или пятихлористого фосфора не представляется возможным из-за отсутствия активных центров фосфорилирования. Экспериментально было показано, что реакция протекает при длительном нагревании в течение не менее 48 ч 
в атмосфере аргона исходного ацилпроизводного гликолурила и пятихлористого фосфора в соотношении 1:6 и приводит к образованию дифосфонового комплекса тетраацетилгликолурила - дигексахлорофосфорат 2,6-ди-(4,8-диацетил-2,4,6,8-тетраазабицикло[3.3.0]октан-3,7-дион)-2,6-ди(хлорэтенилтрихлорфосфония), представляющего собой неустойчивое на воздухе белое кристаллическое вещество. Разложение дифосфонового комплекса было проведено с использованием бензальдегида и протекало с образованием соответствующего дихлорфосфатного производного, так же неустойчивого на воздухе и быстро разлагающегося при комнатной температуре.

Ключевые слова: гликолурил, бисмочевина, пентахлорид фосфора, фосфорилирование, $\mathrm{N}$-ацилирование, фосфор, бициклические, синтез.

\section{References}

1 Bakibaev, A.A., Gorshkova, V.K., \& Yagovkin, A.Yu. (1994). Synthetic anticonvulsants, antihypoxics, and inducers of the liver monooxygenase system based on amides and ureas. XVI. Studies of the antihypoxic properties of bicyclic bis-ureas. Pharm. Chem. J., 8, 547. https://doi.org/10.1007/BF02219026

2 Salkeeva, L.K., Bakibaev, A.A., \& Khasenova, G.T. (2016). Effect of Glycoluril and Its Derivatives on the Flame Resistance and Physicomechanical Properties of Rubber. Russian Journal of Applied Chemistry, 89, 1, 132-139.

3 Grillon, E., Gallo, R., Pierrot, M., \& Boileau, J. (1988). Isolation and X-ray structure of the intermediate dihydroxyimidazolidine(DHI) in the synthesis of glycoluril from glyoxal and urea. Tetrahedron Lett., 29, 9, $1015-1016$. https://doi.org/10.1016/0040-4039(88)85322-X

4 Jarvo, E. R., \& Miller, S.J. (2002). Amino acids and peptides as asymmetric organocatalysts. Tetrahedron Lett., 58, 24812495. DOI: $10.1016 / \mathrm{S} 0040-4020(02) 00122-9$

5 Christoffers, J., \& Mann, A. (2001). Enantioselective Construction of Quaternary Stereocenters. Chem. Int. Ed., 40, 45914597. https://doi.org/10.1002/1521-3773(20011217)40:24<4591:aid-anie4591>3.0.co;2-v

6 Krause, N., \& Hoffmann-Roder, A. (2001). Recent advances in catalytic enantioselective Michael additions. Synthesis, 171196.

7 Sibi, M.P., \& Manyem, S. (2000). Enantioselective conjugate additions. Tetrahedron Lett., 56, 8033-8061. https://doi.org/ 10.1016/S0040-4020(00)00618-9

8 Leonard, J., Diez-Barra, E., \& Merino, S. (1998). Control of Asymmetry Through Conjugate Addition Reactions. Eur. J. Org. Chem., 2051-2061.

9 Bakibaev, A.A., Hoang, N.P., Malkov, V.S., Gorbin, S.I, \& Panshina, S.Yu. (2019). Tetraatsetilhlikoluril i nekotorye eho proizvodnye: sintez, svoistva i primenenie [Tetraacetylglycoluril and its derivatives: synthesis, properties and application]. Izvestiia vysshikh uchebnykh zavedenii - Russian journal of chemistry and chemical technology, 62, 9, 4-19. https://doi.org/10.6060/ivkkt.20196209.5924 [in Russian].

10 Salkeeva, L.K., Taishibekova, E.K., Bakibaev, A.A., Minaeva, E.V., Sugralina, L.M., \& Salkeeva, A.K. et al. (2017). New Phosphorylated Glycoluril Derivatives. Russ. J. Gen. Chem., 87, 3, 442. https://doi.org/10.1134/S1070363217030124

11 Pudovik, A.N., \& Khairullin, V.K. (1968). Reaktsii haloidanhidridov kislot fosfora s nepredelnymi soedineniiami [Reactions of phosphorus acid halides with unsaturated compounds]. Uspekhi khimii - Advances in chemistry, 37, 745-777. https://doi.org/10.1070/RC1968v037n05ABEH001638 [in Russian].

12 Promonenkov, V.K., \& Ivin, S.Z. (1968). Sposoby polucheniia i svoistva soedinenii s nepredelnymi radikalami pri atome fosfora [Production methods and properties of compounds with unsaturated radicals at the phosphorus atom]. Uspekhi khimii - Advances in chemistry, 37, 1577-1599 [in Russian]. https://doi.org/10.1070/RC1968v037n09ABEH001699

13 Kosolapoff, G. M., \& Huber, W.F. (1946). Addition Reactions in Phospho-organic Syntheses. The Addition of Phosphorus Pentachloride to Olefins. J. Am. Chem. Soc., 68, 2540-2541. https://doi.org/10.1021/ja01216a034

\section{Information about authors:}

Salkeeva, Lyazat Karishovna - Doctor of Chemical Sciences, Professor of the Organic Chemistry and Polymers Department, Karagandy University of the name of Academician E.A. Buketov, Kazakhstan, Karagandy, 100024, Universitetskaya str., 28. E-mail: 1salkeeva@mail.ru; https://orcid.org/0000-0003-4207$916 \mathrm{X}$

Muratbekova, Aigul Akizhanovna - Candidate of Chemical Sciences, Associate Professor of the Chemical Technology and Petrochemistry Department, Karagandy University of the name of Academician E.A. Buketov, Kazakhstan, Karagandy, 100024, Universitetskaya str., $28 . \quad$ E-mail: aigulmuratbekova@mail.ru; https://orcid.org/0000-0002-2156-9306

Minayeva, Yelena Viktorovna - Candidate of Chemical Sciences, Associate Professor of the Organic Chemistry and Polymers Department, Karagandy University of the name of Academician E.A. Buketov, Kazakhstan, Karagandy, 100024, Universitetskaya str., 28. E-mail: yelenaminayeva@yandex.ru; https://orcid.org/0000-0001-9382-5965 
Vojtíšek, Pavel - Associate Professor RNDr., CSc. Charles University of Prague, Czech Republic, Prague, 400 96, Pasteurova 1. E-mail: pavojt@ natur.cuni.cz; https://orcid.org/0000-0002-4685-9238

Tateeva, Alma Baymaganbetovna - Candidate of Chemical Sciences, Associate Professor of the Chemical Technology and PetrochemistryDepartment, Karagandy University of the name of Academician E.A. Buketov, Kazakhstan, Karagandy, 100024, Universitetskaya str., 28. E-mail: almatateeva@mail.ru; https://orcid.org/0000-0002-4538-9457

Salkeeva, Ayzhan Karishovna - Associate Professor of the Physics Department, Karagandy Polytechnic University, Kazakhstan, Karagandy, 100027, Nursultana Nazarbaeva str., 56. E-mail: asalkeeva58@mail.ru; https://orcid.org/0000-0002-2277-7959

Tayshibekova, Ekaterina Karimovna - PhD, Lecturer at the Organic Chemistry and Polymers Department, Karagandy University of the name of Academician E.A. Buketov, Kazakhstan, Karagandy, 100024, Universitetskaya str., 28. E-mail: ekaterina_teishi@mail.ru; https://orcid.org/0000-0001-5557-9177

Dostanova, Aida Ruslanovna $-2^{\text {nd }}$ year master's student. Karagandy University of the name of Academician E.A. Buketov, Kazakhstan, Karagandy, 100024, Universitetskaya str., 28. E-mail: Dostanova1997@mail.ru; https://orcid.org/0000-0002-7460-9682 